\title{
Personal Insolvency Law and the Demand for Venture Capital
}

\author{
John Armour*

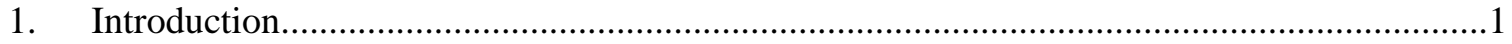

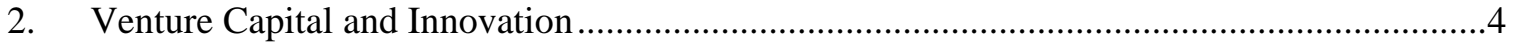 \\ 3. Legal and Institutional Determinants of Venture Capital Finance .........................................6 \\ 4. Personal Insolvency Law and Demand for VC Finance .......................................................8 \\ 4.1 Ex ante: personal insolvency law and incentives for risk-taking ................................. \\ 4.2 Ex post: the financial rehabilitation of former insolvents ............................................9 \\ 5. A Preliminary Test: How Does VC Investment Vary with the 'Severity' of Personal

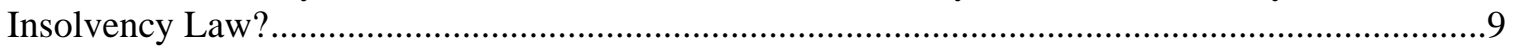 \\ 5.1 How Do Personal Insolvency Laws Differ in 'Severity'?..........................................10

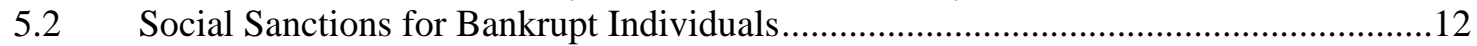

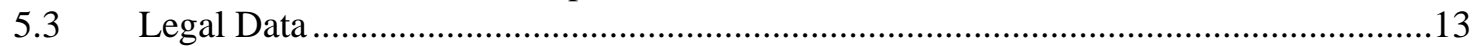

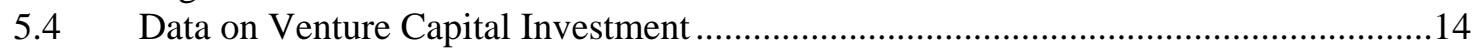 \\ 5.5 How Does VC Investment Relate to Personal Insolvency Law? ..................................15 \\ 6. Financing Policy and Corporate Insolvency Law ............................................................17

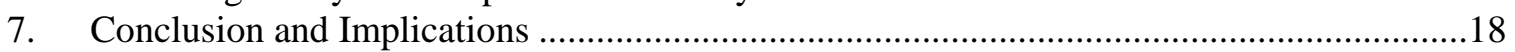 \\ Appendix: Personal Insolvency Laws of Different Countries ...................................................25
}

\begin{abstract}
Scholars working in the 'law and finance' field have investigated empirically the links between various types of law and the incidence of venture capital finance. However, no study to date has systematically investigated the relationship between insolvency law both personal and corporate - and venture capital finance. This paper argues that a nation's personal insolvency law may have an important impact on the demand for venture capital finance, with more severe treatment of insolvents tending to reduce demand. This hypothesis is subjected to a preliminary test by comparing data on venture capital investment activity with an index of 'severity' of insolvency laws, and is not falsified. This finding will be of interest to policymakers, as a number of recent national and EU initiatives have sought explicitly to encourage innovative firms and venture capital finance.
\end{abstract}

\section{Keywords:}

\section{INTRODUCTION}

Venture capital is used to finance a small minority of companies with the potential and ambition to grow rapidly. It is thought to be of disproportionate importance in stimulating

\footnotetext{
* Faculty of Law and Centre for Business Research, University of Cambridge. I gratefully acknowledge funding from the ESRC. For helpful comments and discussions, I thank Robert Ahdieh, Jöchen Bigus, Douglas Cumming, Kevin Davis, Henry Hansmann, Joe McCahery, Richard Nolan, Ed Rock, Erik Vermeulen, Michael Wachter and Wolfgang Weigel. I am also grateful to seminar participants at Athens University (EALE 19th), Tilburg University, the University of Pennsylvania Law School, the Cass Business School and Yale Law School.
} 
innovation. Start-up companies with new business ideas and high growth potential, but lacking liquid assets, may be unable to obtain bank finance because of the high risk they present. Venture capital involves the supply of equity finance - so the investor shares in the benefits of high growth - along with 'hands-on' governance so as to assist in bringing about the success of investee companies. A number of recent national and EU policy initiatives have sought explicitly to encourage innovative firms and venture capital finance (Department of Trade and Industry, 2001; European Commission, 1998, 2000, 2003). At the same time, scholars working in the 'law and finance' field have investigated empirically the links between various types of law and the incidence of venture capital finance (e.g. Black and Gilson, 1998; Gompers and Lerner, 1999; Jeng and Wells, 2000; Cumming and MacIntosh, 2002).

A number of legal and institutional factors have been identified in the literature as potentially important in facilitating investment by venture capitalists. It is possible to categorise these factors according to whether they impact upon the willingness of investors to advance private equity finance to small, high-growth firms (the 'supply side'), the likelihood that entrepreneurs will engage in activity requiring such finance (the 'demand side'), or both (Gompers and Lerner, 1999). Thus, it has been claimed that rates of capital gains taxation are an important variable affecting the demand for venture capital finance - the lower the applicable rate, the greater the potential returns to entrepreneurship. Conversely, studies have demonstrated a link between the regulation of institutional investment and the supply of venture capital - most notably, restrictive prudential regulation of pension funds may inhibit the supply of capital to start-up firms. Perhaps the best-known claim in this literature is that of Black and Gilson (1998): that the existence of deep and liquid stock markets is an important stimulus for both supply of, and demand for, this type of finance. However, no study to date has systematically investigated the relationship between insolvency law - both personal and corporate - and venture capital finance. This is perhaps surprising, given that reform of insolvency law is or has recently been on the agenda in a number of countries, including Belgium, France, Germany, Italy, the Netherlands, Sweden, the UK and the US.

The analysis presented in this paper results a relatively modest descriptive claim: that insolvency law may have an important impact on the levels of venture capital investment observed across different countries. The way in which this claim is developed is perhaps counter-intuitive. At first blush, we might point to the ubiquitous availability of limited liability through incorporation, and think that personal insolvency law would be a relatively unimportant determinant of demand for venture capital. However, this would ignore the potential financial burdens imposed on entrepreneurs prior to incorporation and the common incidence of personal guarantees of corporate debts. Thus the failure of an incorporated business may often result in the personal insolvency of its founders. In a population with heterogeneous risk preferences, the treatment of individuals by insolvency law might therefore be expected to have an ex ante impact on incentives to engage in entrepreneurship, and consequently demand for venture capital finance. Furthermore, the treatment of individual bankrupts might also have an ex post effect. A harsh law of personal insolvency may mean that entrepreneurs whose businesses fail through no fault of their own, and who often possess considerable human capital, are 
legally disabled from inclusion in the pool of talent in which venture capitalists seek to invest. Again, this could be expected to have an impact on demand for venture capital.

The paper's claim is thus that personal insolvency law may have an important impact on demand for venture finance. Moreover, in the increasingly globalised business environment, it seems plausible that factors that affect demand for venture capital are likely to be more significant determinants of investment activity than factors that affect supply (Mayer, 2001). Both funds for investment and entrepreneurs can move across borders to 'bypass' unfavourable legal regimes. However, it is likely to be considerably more costly for entrepreneurs than for capital to relocate across national borders. Thus national laws which affect the 'demand side' might be expected to be more important determinants of investment levels than those which touch on the 'supply side'. Thus in a globalised financial environment a nation's personal insolvency law may be a significant determinant of its level of venture capital investment.

An analysis of corporate insolvency law's impact is more ambiguous. We might, at least superficially, imagine that a nation's corporate bankruptcy regime would have a significant effect on the incidence of venture capital finance. However, this analysis would the that innovative 'start-up' firms frequently do not have 'hard' assets which might be pledged as collateral for creditors. Thus they are unable to obtain debt finance indeed, this is why entrepreneurs founding such firms turn to venture capitalists in the first place. If there is little debt in a firm's financial structure, then the rules of corporate insolvency law are unlikely to be a major influence on the behaviour of its constituents. Some preliminary observations on these questions are made in Section 6, but detailed consideration is left for future work.

The rest of the paper is structured as follows. Section 2 is primarily directed at readers unfamiliar with the structure of venture capital investments. It sets the scene by outlining the role played by these specialised financiers in supporting innovative high-growth firms. Section 3 offers a brief review of the literature on the legal and institutional determinants of venture capital finance, and sets up the claim that cross-border flows of funds are likely to make 'demand side' factors relatively more important determinants than 'supply side' considerations. Section 4 then theorises the way in which personal insolvency law might impact levels of venture capital finance. This theoretical claim is then subjected to a crude empirical test in section 5. An index of 'severity' of personal insolvency laws is constructed for eleven different countries. Consistently with the theoretical predictions, this is shown to be significantly negatively correlated with national patterns of venture capital investment. Section 6 makes some brief observations about the possible role of corporate insolvency law, and Section 7 is concludes with a discussion of implications. At the outset, it should be emphasised that the limited existing analysis of the relationship between insolvency law and venture capital and the crudeness of the empirical analysis conducted herein reinforce the preliminary nature of this contribution. 


\section{VENTURE CAPITAL AND INNOVATION}

Two features define the landscape in which small firm financing takes place. The first is that small firms display a high degree of 'informational opacity' (Berger and Udell, 1998). Potential financiers thus face severe information asymmetries. Prior to advancing funds, there will be an 'adverse selection' problem (Myers and Majluf, 1984): if the financier offers average terms, these will be attractive to low-quality entrepreneurs, and unattractive to high-quality entrepreneurs. After funds have been invested, the financier will face a 'moral hazard' problem (Jensen and Meckling, 1976): if the business does not prosper and so an inadequate yield is achieved, the financier may not be able to distinguish between whether this was caused by the entrepreneur's lack of effort or pursuit of private benefits, or simple bad luck. This will reduce the entrepreneur's incentives to apply effort and pursue joint benefits.

The second defining feature of small firm finance is that entrepreneurs 'like to be their own boss'. This makes them unwilling to cede control rights to outsiders. Thus entrepreneurs will prefer to finance business development so far as possible with internal funds. If the firm is wealth constrained, however, this will not be possible. When external finance must be sought, the equilibrium financial contract will be one which mitigates the information asymmetries without ceding control to the financier. For many firms, this will be done through debt finance. Debt finance involves a contingent allocation of rights to control business assets between the entrepreneur and the financier (Aghion and Bolton, 1992; Hart, 1995). Provided that the entrepreneur meets the agreed payments, the financier will receive the contractually agreed rate of return and the entrepreneur retains control of the assets. Should the entrepreneur be tempted to slack, or pursue private benefits that will harm financial returns, then the probability of meeting the agreed payments will lessen. If the entrepreneur defaults on repayment, then the investor has the right to seize and sell the business assets to repay the sum owed. This would deprive the entrepreneur of control of the business, the fear of which will give him an incentive to apply effort ex ante. Equity finance, in contrast, involves the immediate sharing of control rights with the financier, and so should be expected to be less attractive to entrepreneurs than debt. This hierarchy of preferences for financing is often referred to as the 'pecking order' theory of corporate finance (Myers and Majluf, 1984). It predicts with empirical support (e.g. Berger and Udell, 1998) - that firms will finance projects first with internal funds, then with debt, and only if these sources have been exhausted, with equity.

'Start-up' firms developing new technologies often have difficulties raising debt finance. They commonly do not generate steady cash flows which can be used to make interest payments on debt. For many such firms, the primary assets consist of ideas, ${ }^{1}$ growth

\footnotetext{
${ }^{1}$ Ideas can of course be made alienable through patenting. However, the possibility of selling the patent without the team should not be overstated. First, many start-up firms will not have legally-protected intellectual property rights. On the one hand, their business model may involve exploiting a niche market, which is not itself patentable. On the other hand, their development may be at such an early stage that nothing patentable has yet been produced. Second, merely controlling the patent will not give the investor
} 
opportunities and human capital, which are not capable of being liquidated by a creditor should default occur (see, e.g., Berger and Udell, 1998; Carpenter and Petersen, 2002). Rather, there is a strong complementarity between 'soft' assets and concentrated equity finance, in the form of venture capital. ${ }^{2}$

Venture capital is private equity investment advanced to businesses that are starting up or at an early stage in their development - that is, before the a profit has been earned. ${ }^{3}$ Venture capitalists are active investors, ameliorating agency problems between themselves and their portfolio companies by developing specialist expertise and using sophisticated contractual terms designed both to give the entrepreneur appropriate incentives and to give the investor a significant role in the governance of the firm (Gompers and Lerner, 1999). ${ }^{4}$

On the one hand, the control rights granted to the venture capitalist are not incompatible with the entrepreneur's preference for control. The rights are not used simply to protect the value of their investment in a way that conflicts with what the entrepreneur is seeking to achieve. Rather, a key contribution of venture capitalists is that they 'add value' to their portfolio businesses by bringing managerial talent, consultancy services, assisting in the design of governance structures, hiring key team members, providing access to networks and fostering credibility through the signal of their reputation (Black and Gilson, 1998).

On the other hand, venture capital contracts overcome asymmetries of information between the financier and the entrepreneur by 'staging' the advances of funds. Subsequent 'rounds' of finance may not be available, or only on considerably more expensive terms, if performance targets are not met in the interim. This process gives the venture capitalist control rights over the decision whether or not to continue the project. It is the reverse of the mechanism used by lenders (Triantis, 2001). Instead of pulling assets out of a firm (default on debt) the venture capitalist simply refuses to put more assets in. In either case, the denial of assets leads to closure of the firm's business.

VCs will hold a portfolio of investments for 3-7 years. Successful investments are exited either by listing the company through an initial public offering (IPO) and then selling the

the wherewithal to exploit it. This will still require the human capital of a team with dedicated knowledge of associated technologies, suppliers and customers (both actual and potential). Third, for evolving technologies the value of any individual patent, or series of patents, is highly contingent. Much more value is likely to inhere in a firm which has a team of scientists working to produce a dynamic stream of patentable technology than in a firm which simply owns static patents.

${ }^{2}$ Empirical studies show that equity (venture capital), and not debt, financing, predominates in privatelyheld 'high-tech' firms (Freear and Wetzel, 1990; Carpenter and Petersen, 2002).

3 'Venture capital' is defined by the European Venture Capital Association ('EVCA') as, 'Professional monies co-invested with the entrepreneur to fund an early stage (seed / start-up) or expansion venture. Offsetting the high risk the investor takes is the promise of high return on the investment.' (<http://www.evca.com/html/PE_industry/glossary.asp?action=search\&letter=yes\&AZ=vwxyz $>$ ).

${ }^{4}$ The ways in which venture capitalists in the US, UK and elsewhere overcome these agency problems by contracting and monitoring have been extensively studied empirically. For reviews, see Gompers and Lerner (2001) and Klausner and Litvak (2001). 
venture capitalist's shares, or by selling the company to a competitor (a 'trade sale'). Unsuccessful investments tend to get liquidated. One good investment that results in an IPO can earn enough to cancel out ten write-offs and still generate a healthy overall portfolio return. The foregoing features make venture capital finance particularly well matched to innovative, high-tech firms. As a result, venture capital is thought to be of disproportionate importance in stimulating innovation. ${ }^{5}$

\section{LEGAl AND InSTITUTIONAL DETERMinANTS OF VENTURE CAPITAL FinANCE}

The legal and institutional determinants of aspects of corporate finance - in particular, stock ownership structure and depth and liquidity of stock markets - have been the topic of much recent research (e.g. La Porta et al., 1997). Levels of venture capital investment vary widely across countries, as is demonstrated by Figure 2. Whilst the overall levels of venture capital investment have fluctuated with business cycles, the relative differences between countries have remained roughly constant. Whether, and to what extent, patterns of venture capital investment are influenced by legal and institutional factors that differ by country is therefore an important question for research. Moreover, it is a question of considerable interest to policymakers who may be seeking to foster the development of $\mathrm{VC}$ investment in their countries so as to encourage innovative firms.

[Figure 1 about here]

A country's legal rules and institutional framework might, in various ways, affect either national demand for venture capital finance, the supply of funds for investment, or both. Recent thinking suggests that of the two, factors affecting demand may ultimately have the greater impact upon total levels of national VC investment (Mayer 2001). This is because of differing costs of arbitrage in relation to supply and demand constraints. Funds for investment in venture capital flow readily across borders (Baygan and Freudenberg 2000). Thus transnational capital flows may be able simply to bypass domestic legal 'barriers' to the supply of venture capital. Of course, entrepreneurs are also able to repatriate themselves in favour of jurisdictions where demand-side variables are more favourable to their endeavours. However, the costs of relocation are likely to be greater for entrepreneurs than for investors' funds. As a result, factors which affect demand for venture capital - i.e. those legal variables which may have an impact on the level of entrepreneurial activity - may be relatively more important determinants of observed investment levels than those which affect supply.

The existing literature shows that a variety of different legal rules and institutional structures affect the incidence of venture capital investment across countries. ${ }^{6}$ One important factor, affecting both supply and demand, is the depth and liquidity of stock

\footnotetext{
${ }^{5}$ Kortum and Lerner (2000) and Tykvová (2000) provide evidence that venture capital is disproportionately linked to innovative activity in the US and Germany respectively.

${ }^{6}$ For a fuller review, see Armour (2003).
} 
markets (Black and Gilson, 1998; Jeng and Wells, 2000). ${ }^{7}$ Stock markets facilitate IPOs. An IPO in turn allows venture capitalists to realise the upside return on their investment. More importantly, from the entrepreneur's point of view, an IPO is preferable to a trade sale. A trade sale will involve the purchase of a controlling stake by the buyer, and the likely replacement of the firm's managers. In comparison, an IPO of a successful firm will usually leave the existing management team in place. Thus, ex ante, a venture capital investment agreement which contemplates the possibility of exit by an IPO will be attractive to a wider range of potential entrepreneurs than one which does not.

Much of the finance raised by venture capitalists in the US and UK comes from pension funds, insurance companies and other collective investment mechanisms. Hence pension fund regulation which inhibits fund managers from investing in 'high risk' asset classes such as private equity and venture capital may hinder supply in economies where a large amount of private wealth is tied up in such schemes. ${ }^{8}$ As might be expected, taxes and subsidies also affect levels of VC investment. Gompers and Lerner (2000) show that reductions in rates of capital gains tax stimulate demand for venture capital, by increasing expected returns to entrepreneurs. ${ }^{9}$ In addition, many countries have pursued policies which seek to stimulate investment in venture capital through granting subsidies. ${ }^{10}$ However, such mechanisms may give rise to unintended consequences. For example, it appears that inappropriately designed public venture capital schemes may end up bidding for the same investments as private funds, thereby 'crowding out' the very thing they are intended to stimulate (Cumming and MacIntosh 2002).

A country's law of business organisations may also affect levels of venture capital investment. Where legal entity structures are excessively rigid and do not adequately facilitate contracting with a concentrated investor - such as a venture capitalist - over rights to returns and control in the manner discussed in the preceding sections, this will make investment less attractive. ${ }^{11}$ Moreover, to the extent a nation's organisational law hinders incorporation - and hence the availability of limited liability for entrepreneurs - it may restrict demand for venture capital finance. ${ }^{12}$ However, little academic work has to date considered whether insolvency law may be a determinant of national levels of VC investment. The next section argues that personal insolvency law may affect demand for

\footnotetext{
${ }^{7}$ Jeng and Wells (2000) investigate a range of such factors, including pension fund regulation, capital gains taxation, the size of stock markets, and labour laws.

${ }^{8}$ Gompers and Lerner (1999) report changes in US investment activity in response to changes in the application of pension regulation.

${ }^{9}$ Empirical evidence from US studies suggests that the primary impact of a change in CGT rates is on the demand side (Gompers and Lerner 2000).

${ }^{10}$ These can take various forms, ranging across a spectrum from targeted tax relief granted to investors in venture capital funds, through 'partnership' funds which are partially state-funded and raise private investment as well, and which invest in specific types of firm, to tax relief on stock options and finally direct state investment in high-technology enterprise.

11 For example, Vermeulen (2001) documents the problems which Dutch law's mandatory terms concerning the corporate constitution would create for a US-style venture capital contract.

${ }^{12}$ UK empirical studies report that limited liability is a primary motivation for incorporation by very small businesses (Freedman and Godwin 1994, and Hicks et al. 1995).
} 
VC finance. Given the differential costs of regulatory arbitrage, this may make it potentially a very significant determinant of venture capital investment.

\section{Personal Insolvency LaW AND Demand For VC Finance}

This section develops a theory of how personal insolvency law may affect the incidence of venture capital finance. It posits a link between personal insolvency law and levels of entrepreneurial activity in the economy (Fan and White, 2000; Georgellis and Wall, 2002). If it is assumed that a given proportion of potential entrepreneurs would create high-growth businesses with 'soft' assets that are unsuitable for raising debt finance, then greater levels of entrepreneurship will imply greater demand for venture capital finance. Personal insolvency law may affect the level of entrepreneurship in society in two principal ways (Hallinan, 1986; Czarnetzky, 2000). Ex ante, it may affect the willingness of marginal (potential) entrepreneurs to enter the marketplace on their own, as opposed to remaining in employment. $E x$ post, it will affect the ability of inframarginal entrepreneurs to return to the marketplace after becoming financially distressed. These will be considered in turn.

\subsection{Ex ante: personal insolvency law and incentives for risk-taking}

Assume that risk preferences are heterogeneous in society, and that propensity for ideas is distributed evenly across society. A rational potential entrepreneur will consider the costs and benefits of going into business on his own. The potential 'upside' will be determined by the quality of the idea and the opportunities for exploitation within the economy, neither of which will be known in full at the outset. The 'downside' will also affect the potential entrepreneur's decision. If the idea does not succeed, then the 'worst case' outcome will be personal insolvency.

To see how personal insolvency might happen, imagine a putative entrepreneur who is considering starting a firm. He will not be able to obtain venture capital finance until a reasonably advanced stage of development. To begin with, he will invest personal savings. He may seek funding from family and friends. When these sources are exhausted, he may try to obtain finance from a 'business angel', ${ }^{13}$ and only by the time he has a defined business plan and a reasonably well-developed technology will the firm become an attractive proposition to VCs. If he is successful in raising venture capital backing and the business prospers, then he will become wealthy. However, if he fails to obtain VC finance at the outset, then it is quite possible that he will by this point have over-extended his personal finances and face a risk of personal insolvency. ${ }^{14}$

If personal insolvency law imposes harsh consequences upon the individual, then ex ante the attractiveness of entering into a risky entrepreneurial endeavour will be reduced,

\footnotetext{
13 'Business angels' are wealthy individuals willing to invest at a very early stage of business development. Typically they are themselves successful entrepreneurs.

${ }^{14}$ Even if he succeeds in raising VC backing, the business may subsequently fail before he has had the chance to restore stability to his personal finances.
} 
particularly if the individual is risk-averse. To the extent that personal insolvency is a possibility, a potential entrepreneur's evaluation of the 'downside' risk to business startup will be affected by its consequences. This theory would predict that a harsher personal insolvency law should be related to a reduced demand for venture capital finance, as less entrepreneurs are willing to initiative high-risk businesses. If the personal insolvency regime is made less stringent, then individuals with ideas who are more risk-averse will at the margin find this an acceptable path, and the level of entrepreneurship in the economy will increase.

A potential objection to this theory is that it is often said that entrepreneurs are by nature optimistic and have sufficient belief in their project to discount the risk of failure. In this case, the consequences of personal bankruptcy will be less important to them ex ante. Whilst this observation may well be accurate as a description of inframarginal entrepreneurs, it tells us little about those who choose not to do so because of the fear of bankruptcy.

\subsection{Ex post: the financial rehabilitation of former insolvents}

A second effect of personal insolvency law concerns the ease with which bankrupt entrepreneurs may be rehabilitated into the economy. Bankruptcy is just as likely to occur as a result of macroeconomic instability, or something as difficult to rationalise as 'bad luck', as because of incompetence or on the part of the entrepreneur. Furthermore, the entrepreneur will have gained experience of business management, and the skills necessary to execute a 'start-up'. If such a person has another business idea, the structure of personal insolvency law - and in particular, the availability of a 'fresh start' - will have an impact on their ability to exploit it. The more readily a 'fresh start' is available, the sooner such entrepreneurs can exploit their next idea. If a fresh start is not available, however, then the value of the entrepreneur's human capital to society is lost (Jackson, 1985; Georgakopoulos, 2002).

This effect is entirely independent of the ex ante incentives, which relate to marginal (potential) entrepreneurs. It is often argued that there is more to entrepreneurship than simply a willingness to take risks. Even if this is true in the extreme sense that the set of 'entrepreneurs' is fixed in any given society, and its size cannot be increased by making it less risky to incur credit, the numbers of active entrepreneurs will be depleted if they are disabled from founding their own businesses following personal bankruptcy.

\section{A Preliminary Test: How Does VC InVestment Vary with the ‘Severity’ of PERSONAL INSOLVENCY LAW?}

If the theory outlined in section 4 is accurate, then we should expect national patterns of venture capital investment to vary with personal insolvency law. More precisely, the theory predicts that less venture capital investment will be observed in jurisdictions where the consequences of personal insolvency are 'harsh' than in those where they are relatively 'soft'. If no such correlation is found, the theory will have been falsified. This section reports a preliminary test along these lines. It begins by describing the ways in 
which the 'severity' of consequences of personal insolvency may vary. A crude index of the severity of eleven different regimes is then constructed, and compared with data on the levels of venture capital investment in these countries for the years 1997 through 2000 .

\subsection{How Do Personal Insolvency Laws Differ in 'Severity’?}

Crucial to the meaningful testing of the theory are the means by which the 'severity' of personal insolvency laws are assessed. To do this, it is necessary first to survey, at a fairly general level, the sorts of consequences which may accompany personal insolvency, then to identify the ways in which these consequences differ meaningfully across jurisdictions, and finally to focus on those differences which are likely to be significant for the purposes of the theory outlined in section 4 . What, then are the typical consequences of personal insolvency? ${ }^{15}$

Generally speaking, personal insolvency proceedings typically result in a divestment of the debtor's ownership of her assets in favour of an official trustee, who will liquidate them in order to raise money to pay creditors. The divestment can vary in its completeness. In some jurisdictions the debtor remains 'owner' of her assets, whereas in others there is a complete transfer to the trustee. The purpose of the divestment is to prevent the debtor from alienating assets to the detriment of creditors, and to allow for their realisation in an orderly fashion by an outside appointee. Hence in jurisdictions where the debtor retains (some) ownership rights, there are nevertheless usually restrictions on her ability to alienate assets, at least without the consent of the trustee.

Concomitantly with the debtor's divestment, the individual claims of creditors will usually be stayed. The function of this rule is well-understood: its purpose is to prevent wasteful duplication of proceedings, and, where there is a 'going-concern' surplus to sale of business assets as a collective, to ensure that this is not lost through uncoordinated enforcement activity leading to a piecemeal liquidation of assets (Jackson, 1985). Almost universally associated with the idea of divestment of assets and a stay of claims is the concept of the creation of a 'bankrupt estate': namely the patrimony of the debtor which is available for collective realisation on behalf of the creditors. A potentially significant difference between jurisdictions concerns the scope of exemptions from the estate. In most jurisdictions, the debtor is permitted to retain full ownership of personal effects and tools of her trade. However, in some jurisdictions the scope of the exemptions may be much more generous.

Personal insolvency will often have a range of other consequences for the debtor apart from the divestment of personal assets. Most importantly, the debtor's legal status may be affected, such that he is subject to disabilities in her interactions with other persons. For example, he may be disbarred from engaging in commercial activities and/or participating in the management of a limited company, obtaining credit (above a certain

15 Wood (1995: 1-34) offers a useful overview of different features common to many insolvency procedures. 
amount), holding political office etc., etc. The extent of these disabilities will vary from jurisdiction to jurisdiction, along with the length of time for which they are imposed.

Perhaps the most important difference, however, concerns the availability (or otherwise) of a 'fresh start' following personal insolvency proceedings. The concept of a fresh start is well-known: the debts of the insolvent are 'discharged' after a certain period of time following the commencement of proceedings, and he is free to return to the marketplace free of her obligations to repay them. This allows her to enjoy once more the fruits of her productive capacity, and removes disincentives to investment in human capital, etc, which would otherwise obtain were he denied such an opportunity. Many jurisdictions do not permit a discharge of debts following insolvency. For those that do, the length of time which must elapse, and the other conditions which must be fulfilled (e.g. demonstration of good behaviour), vary considerably.

Another important aspect of personal insolvency proceedings will be the treatment of assets acquired after the proceedings have begun. If a discharge has occurred, then the debtor will be free to enjoy them subject to any non-discharged obligations to her creditors. Conversely, if a discharge has not occurred, then these new assets will be available for the payment of creditors. If the trustee is still in situ, then income may be treated as falling into the estate, and hence available for distribution by the trustee, subject to an exemption whereby the debtor may retain sufficient income to sustain herself and her family. Alternatively, if the proceedings have finished, then the income may belong to the debtor, but be susceptible to levying by her creditors.

In seeking to operationalise the theory developed in this paper, we might therefore speak of the 'severity' of a personal insolvency law as being be a function of the following factors: (i) the existence of a legally-sanctioned 'fresh start', and the circumstances under which it is available; (ii) the range and restrictiveness of the disabilities imposed upon an individual who becomes personally insolvent; and (iii) the level of exemptions (if any) of property from the insolvent estate.

The way in which these factors differ across legal regimes may be illustrated by reference to two countries for which detailed legal materials are available in English, namely the UK and the US. In the UK, the estate of the bankrupt, minus certain exemptions, is taken over by a trustee and sold for the benefit of his creditors (Fletcher, 2003). The exemptions include items for the bankrupt's personal use in employment and clothing and household items required for his basic domestic needs and those of his family. The bankrupt is then subject to certain legal disabilities for a three-year period, ${ }^{16}$ including an inability to incur credit of more than $£ 250$ without disclosing his status as a bankrupt, a ban on trading under a different name without disclosing the name under which he was declared bankrupt, and being disqualified from participating in the management of a limited liability company. During this time, the whole of the bankrupt's income apart from a very modest living allowance must be transferred to the trustee for the benefit of his creditors.

${ }^{16}$ The period may be reduced to two years for cases involving total debts of less than $£ 20,000$. 
At the end of three years, the 'first time' bankrupt receives a 'discharge' and all legal disabilities cease. ${ }^{17}$

In the US, an individual debtor may opt either to enter bankruptcy proceedings under either Chapter 7, Chapter 11 or Chapter 13 of the Federal Bankruptcy Code (Tabb, 1997). Chapter 7, the most frequently used, normally provides a debtor with an immediate automatic discharge from most of his debts, in return for handing over all of his nonexempt assets for the benefit of creditors. ${ }^{18}$ From this point onwards, no creditor may seek to collect pre-bankruptcy debts from the debtor, and the debtor may keep the proceeds of any subsequent earnings. There is no specified period during which the debtor is subject to legal disabilities, and proceedings typically take around 3-4 months to finalise. The range of property which is exempt from the bankrupt estate is largely defined by reference to the state in which the debtor has been domiciled for the 180 days preceding the filing. ${ }^{19}$ The level of exemptions varies widely, the most notoriously generous being the 'homestead' exemptions under Florida and Texas law, which allow the debtor to retain an interest in his home of unlimited value. However, in some other states, such as Pennsylvania, the debtor is allowed to exempt no more than a total of $\$ 300$-worth of property. ${ }^{20}$

\subsection{Social Sanctions for Bankrupt Individuals}

It is a truism that some of the most unpleasant consequences of personal bankruptcy do not result directly from the legal procedures involved, but rather flow from the social stigmatisation of those who become bankrupt (European Commission Expert Group, 2003). Some degree of social stigma is of course universal, but anecdotal evidence suggests that it varies by jurisdiction. For example, it is commonly said that the social stigma associated with bankruptcy in the US is far lower than in most European jurisdictions. Social stigma can be understood as a form of reputational sanction administered by others in the community. Bankruptcy is a matter of public record, and can act as a strong signal of financial irresponsibility, thereby making it rational for lenders or other business partners to shun the debtor. Furthermore, there may be a loss of esteem from other individuals associated with this public signal of failure. These effects will mean that the adverse consequences of bankruptcy to an individual may extend for much longer than the formal legal proceedings.

We should not, however, conclude that the possibility that social stigma may increase the total penalty 'experienced' by a debtor, that changes to the legal regime will not affect levels of entrepreneurship. Whilst the stigma effects described do not flow directly from

\footnotetext{
${ }^{17}$ If the individual was previously discharged from bankruptcy less than 9 years beforehand, then discharge is not automatic.

${ }^{18} 11$ USC $\S \S 524,727(a)$.

1911 USC $\S 522(b)$.

${ }^{20}$ There are a number of grounds for denying discharge, perhaps the most important of which is that a discharge may not be granted more than once every six years. Furthermore, if the court considers that the debtor is committing a 'substantial abuse' of the system by not filing for Chapter 13, under which a debtor enters into a repayment compromise with his creditors lasting three years, then it may also dismiss the case.
} 
the legal treatment of insolvency, the design of legal sanctions may affect the way in which society reacts to bankruptcy. This is because the 'severity' of bankruptcy law can be expected to have a direct effect on the numbers of individuals who become bankrupt. Whether by entering business as entrepreneurs, or by taking on large levels of consumer debt, a relaxation of the legal consequences of bankruptcy can be expected to make more individuals willing ex ante to run the risk of becoming unable to pay their debts. As the numbers of bankrupts increase, the reliability of bankruptcy as a signal of financial irresponsibility will decrease. Consequently, it is to be expected that the social stigma attached to bankruptcy will decline. ${ }^{21}$ On this theory, the social stigma of bankruptcy is endogenous to the severity of the bankruptcy law's consequences upon individuals, and so the latter may be thought of as a reasonable proxy for the former.

\subsection{Legal Data}

Eleven jurisdictions (Belgium, Denmark, France, Germany, Ireland, Italy, the Netherlands, Spain, Sweden, the UK and the US) were selected for analysis. The selection criteria were the availability of data concerning their insolvency codes and levels of venture capital investment, and the existence of a reasonably well-developed venture capital industry in each case. Summary details of the relevant insolvency laws are presented in the Appendix. These data were used to construct an ordinal index of the relative ‘severity' of bankruptcy for individuals, as set out in Table 1.

The index was constructed on the basis of the number of years it is necessary for an individual to wait prior to obtaining a discharge from indebtedness. This criterion was selected because it is relatively simple to measure and compare, and subject to a wide range of values across the countries considered. In contrast, there is considerable homogeneity of treatment of exempt assets in European jurisdictions. Almost everywhere, the debtor is allowed to retain personal effects and a modest living allowance, but little else. The relatively small degree of variance in asset exemptions means that this factor is unlikely to have much influence on relative demand for venture capital. The exception is the US, where the existence and extent of the so-called 'homestead' exemption is a matter left to state law. ${ }^{22}$ The legal disabilities associated with personal insolvency do vary from country to country, but are often conditioned upon slightly different events - e.g. fraud, negligence, etc., or of slightly differing scope. For simplicity, they are not taken into account in the index used in this paper. ${ }^{23}$

\footnotetext{
${ }^{21}$ This theory is borne out by a consideration of changing attitudes towards personal insolvency in the US, from the mid-nineteenth to late twentieth centuries: see Hallinan (1986).

${ }^{22}$ Within the US, the size of the so-called 'homestead' exemption varies considerably from state to state. A link between levels of entrepreneurship and the size of the homestead exemption in different states in the has been demonstrated by Fan and White (2000), who found that the level of exemptions were significantly correlated with the incidence of owner-managed businesses. Whilst they did not investigate the way in which venture capital investment varied by state, their study nevertheless provides strong indirect support for the thesis in this paper.

${ }^{23}$ The results reported in the paper were robust to a number of different specifications that were considered using data on disabilities.
} 
The length of time to discharge might be expected to have an impact on both the ex ante and ex post effects discussed in section 4 . On the one hand, the longer the period until discharge, the more 'severe' the downside consequences of failure that will be taken into consideration by the marginal entrepreneur. On the other hand, an undischarged bankrupt will be unable to raise fresh finance, as assets falling into his patrimony will be available for the benefit of his creditors. This means that ex post a bankrupt will find it difficult to start a fresh business until he has been discharged.

A five-point scale was used to classify differing regimes' approaches to discharge, with points representing:

$1=$ immediate discharge available (i.e. less than one year);

2 = discharge available after more than 1 year but less than 5 years;

3 = discharge available after more than 5 years but less than 10 years;

$4=$ discharge available after more than 10 years;

$5=$ no discharge available.

Where the laws had changed during the period 1997-2000 (as in the cases of Belgium, Germany and the Netherlands), the time to discharge is shown under both the old and the new laws, with the results for the former regime displayed in brackets.

[Table 1 about here]

Two further observations should be made. First, fraud is a universal bar to discharge, and so the coding proceeds on the assumption that the debtor has not been fraudulent. ${ }^{24}$ Secondly, the availability of 'discharge' in this analysis is taken to mean discharge by the court regardless of the consent of creditors. In all the jurisdictions surveyed, it is possible for a debtor to obtain a discharge of sorts through reaching a compromise with creditors, utilising a statutory 'cram-down' procedure. Hence a more meaningful comparison is whether the debtor can obtain a discharge if creditors are not willing to consent.

\subsection{Data on Venture Capital Investment}

Annual data on levels of venture capital investment are published by private equity trade associations. Figures for European jurisdictions were obtained from the European Venture Capital Association's annual yearbooks. US data were obtained from the PricewaterhouseCoopers/Venture Economics/NVCA MoneyTree survey. ${ }^{25}$ In keeping with the definition of 'venture capital' used in this paper, attention is restricted to earlystage and expansion finance. ${ }^{26}$ Later-stage, replacement, and MBO finance are thus not included. In order to take into account variances in the size of national economies, total

${ }^{24}$ As the bar is common to all jurisdictions where discharge is available, it is of little interest for the purposes of comparative analysis.

${ }_{25}^{25}$ These data were downloaded from <www.pwcmoneytree.com/> in March 2002.

${ }^{26}$ The classifications of 'early stage' and 'expansion' finance used in the US and European surveys are similar. The surveys are not, however, mutually co-ordinated, and so do not correspond precisely in their classifications. 
venture capital investment for each of the years 1997-2000 inclusive was divided by GDP, measured in millions of US dollars, to give the annual investment levels per million dollars of GDP. ${ }^{27}$ Table 2 presents data on levels of venture capital investment in these 11 countries for each of the years 1997-2001.

[Table 2 about here]

\subsection{How Does VC Investment Relate to Personal Insolvency Law?}

Combining the investment figures with the data on insolvency laws yields a set of 44 country-year observations. ${ }^{28}$ Table 3 presents descriptive statistics for the data and the natural logarithm of the level of venture capital investment per \$m of GDP.

[Table 3 about here]

The analysis in section 4 implies that a more severe personal insolvency law will reduce the incidence of venture capital finance. This hypothesis would be falsified by the data is no significant association is shown between severity of bankruptcy regime and levels of investment.

Figure 2 shows a scatter plot of the raw data. As can be seen, there appears to be a linear relationship, with a negative gradient, between severity of bankruptcy law and levels of venture capital investment. ${ }^{29}$ Strictly speaking, the index of 'severity' of personal insolvency laws yields only ordinal data, because the scale involves a subjective element of classification. As a result, it cannot be guaranteed that each 'step' on the scale is of equal size, and hence tests which rely upon the distances of data points from the mean can yield misleading results. Hence the safest techniques for determining whether the apparent relationship between the two variables is statistically significant are nonparametric tests, which require only that the data be ranked, but do not require that it be ranked on scales of equal intervals. Table 4 reports the results of two such tests: Kendall's $\tau$-b and Spearman's rank-order correlation, which rely upon relative differences in rank ordering in the data. Both show a reasonable degree of negative correlation between the two variables, that is statistically significant at the 0.01 level. This means that we can be $99.9 \%$ confident of rejecting the null hypothesis that there is no correlation between the variables.

[Figure 2 about here]

A simple ordinary least-squares regression was also run on the data. For the reasons explained above, this technique may not be considered strictly appropriate. However, the method by which the scale of personal insolvency law 'severity' was constructed is

\footnotetext{
${ }^{27}$ All dollar figures reflect 2002 prices and exchange rates.

${ }^{28}$ These are panel data, as they track each of the 11 countries across time. However, there have only been two significant changes in legal rules during this time, and so there is almost no variation in severity of personal insolvency laws across time. For this reason, the data are treated as a pooled cross-section.

${ }^{29}$ This relationship is also present for each of the individual years within the dataset.
} 
related to the number of years until discharge, and hence may be sufficiently approximate to an interval scale to be capable of yielding meaningful results, provided that they are interpreted with sufficient caution. Furthermore, there are well-known precedents in the 'law and finance' literature for the use of regression analysis involving indices constructed by subjective classification of legal rules (see e.g. La Porta et al., 1997). The format of the presentation of the results in this section follows that adopted by Black (2001).

Linear regression analysis depends crucially on the normality of the distribution of the dependent variable. However, the data on levels of VC investment are not normally distributed, and so this variable was not regressed directly on 'severity', but rather was subjected to a logarithmic transformation. Thus ln (VC investment per \$m GDP) (as dependent variable) was regressed on severity of personal insolvency law (as independent variable), with a constant term as the only other independent variable. The resulting regression equation is as follows:

Ln (VC investment) $=7.999-0.306$ (severity of personal insolvency laws)

$$
(t=-4.28, p<0.001, F=18.32)
$$

Figure 3 shows a scatter plot of these variables.

[Figure 3 about here]

The Pearson correlation coefficient, which shows the strength of the correlation between the two variables, is -0.551 . This is different from its direction, which is given by the slope of the regression line. The $R^{2}$ for this regression, which indicates the fraction of the variance of the dependent variable that is explained by the variance of the independent variable, is $0.304-$ i.e. $30 \%$. This is not particularly strong, and provides another reason for caution in interpreting the results. Nevertheless, given the relatively small sample size and the wide range of other factors which may affect levels of venture capital investment, this is not unsurprising.

The tests conducted in this section are of course extremely basic, given that they do not attempt to account for any of the other factors which might affect the differences in observed investment levels. Hence the results cannot be interpreted as more than suggestive of a negative correlation between severity of personal insolvency law and levels of venture capital investment. ${ }^{30}$ However, the data do display a correlation in the manner predicted by the theory outlined in section 4 . Had no such relation been found, then it would have demonstrated that the theory was false.

\footnotetext{
${ }^{30}$ A more sophisticated test of the theory is reported in Armour and Cumming (2004), in which supply and demand equations for venture capital investment are estimated over 13 years of data from 15 countries. Personal insolvency law is shown to have a small but statistically significant impact upon demand for VC finance, even when controlling for a wide range of other factors.
} 


\section{FINANCING POLICY AND CORPORATE INSOLVENCY LAW}

It is possible that both demand for, and investors' willingness to supply, private equity finance to small firms might also be affected by a nation's corporate insolvency law. A detailed consideration of this issue is outside the scope of this paper, but some preliminary observations may be made. Broadly speaking, there are two ways in which intuition suggests corporate insolvency law might be a potential determinant of VC investment. First, the degree to which corporate insolvency laws respect creditors' preinsolvency entitlements. Generally speaking, credit can be expected to be more difficult to obtain, and equity correspondingly easier, in a country with a corporate bankruptcy regime that does not respect the 'absolute priority rule', namely that creditors must always be paid before shareholders. ${ }^{31}$ Breach of the APR might simultaneously have the effect of reducing the supply of credit and stimulating demand for outside equity.

However, there are reasons for thinking that corporate insolvency law is unlikely to have as significant an impact as we might at first think. The foregoing analysis posits an ex post transfer from creditors to shareholders, which in effect subsidises equity investment. When this is priced ex ante, it can be expected to result in cheaper equity and more costly debt. However, a crucial assumption underlying this reasoning is that the firm seeking finance does indeed have a significant portion of its financial structure supported by debt. If this is not the case, then there can be no ex post transfer, and hence the effect of corporate insolvency law will be negligible. Recall that, according to the 'pecking order' theory of corporate financial structure, the very reason high-growth 'start-up' firms are driven to seek venture capital finance in the first place is that their lack of 'hard' assets means they are unable to support debt finance. Thus for the sorts of firms which typically raise venture capital finance, whether corporate insolvency law is debtor- or creditorfriendly is unlikely to make a significant difference.

To put the matter another way, there is likely to be very little in the way of assets to reorganise if a venture-backed company goes into insolvency proceedings. The inability to pay trade creditors will likely have been precipitated by the venture capitalist deciding not to continue funding the firm. Given that the existing $\mathrm{VC}$ will have good information about the quality of the firm's projects, it is unlikely to be able to obtain replacement finance at this stage from elsewhere. For the same reasons, a sale of the business as a going concern in insolvency will not be feasible. So what will be left? Given that there will be few liquid assets, there is unlikely to be much to fight over at all (Bratton, 2002; Gilson \& Schizer, 2002; see also Gebhard, 2000; Corcoran, 2002). Informal interviews with three venture capitalists conducted by the author have lent support to this assertion: in the interviewees' experiences, insolvencies were usually 'complete write-offs' of the investment concerned. Indeed, given that venture capitalists' investments are typically structured as preferred equity, which will receive a liquidation payment ahead of ordinary shareholders, VCs have an incentive to seek to close failing portfolio companies before they become technically insolvent, so that at least part of their investment may be recaptured in a solvent liquidation.

\footnotetext{
${ }^{31}$ This result is modelled formally by Gangopadhyay and Wihlborg (2001).
} 
Corporate insolvency law might affect the incidence of venture capital finance in a second fashion. In many jurisdictions, personal liability is imposed upon directors of insolvent companies who are found to have been negligent or reckless in the period immediately prior to insolvency. ${ }^{32}$ Other adverse consequences in some jurisdictions include criminal penalties and a ban on being involved in the management of businesses. Whilst such sanctions are almost always conditional upon the directors having been culpable, they may have the effect ex ante of deterring marginal entrepreneurs, and also venture capitalists, from wishing to become involved in business start-up. This effect might be expected to be more pronounced the onerous the penalties and the lower the necessary degree of culpability. Intuitive as this may be, there are reasons for thinking that this effect too may not be as significant as it at first seems. As has been explained, the VC's will often have incentives to try to liquidate investments before they become insolvent. This will mean that wrongful trading, or similar forms of liability, is unlikely to be a matter of concern to investors or entrepreneurs ex ante. However, further research is required in order to establish whether these effects are in fact significant.

\section{CONCLUSION AND IMPLICATIONS}

This paper has sought to contribute to understanding of the legal and institutional determinants of venture capital investment. It has focused on the role played by insolvency law, an area not examined in detail in the existing literature, and argues that a nation's personal insolvency law is an important factor affecting of the levels of venture capital finance.

The theory developed in section 4 suggests that personal insolvency law may affect demand for VC in two ways. Ex ante, a 'harsh' bankruptcy regime may act as a deterrent to potential entrepreneurs who are considering founding a high-growth technology firm. Ex post, a legal regime which does not facilitate the financial rehabilitation of bankrupt individuals may result in the exclusion of talented entrepreneurs from the business startup arena, where risky businesses fail through no fault of the founders. Either or both of these effects can be expected to have an impact on the demand for VC finance. The index of 'severity' of personal bankruptcy laws developed in section 5 lends some support to this hypothesis. Were the hypothesis false, we would expect to see no correlation between severity of the legal regime and the levels of venture capital investment. The ordinal classification of legal rules necessarily involves an element of subjectivity, but this was minimised to the extent possible by linking the aspects of the laws which were 'measured' as closely as possible to the feature which the theory predicted would be most important: the availability, and terms of, a 'fresh start' in bankruptcy. Whilst the statistical techniques applied to measure this correlation are relatively crude and therefore the results can only be treated as preliminary, the analysis of the data suggests a correlation between the legal rules and investment levels, and hence the hypothesis has not been falsified by this test. Conversely, it has been suggested in section 6 that

\footnotetext{
${ }^{32}$ For example, in the UK, liability may be imposed under section 214 of the Insolvency Act 1986 for 'wrongful trading'.
} 
corporate insolvency law could be a less important determinant of national levels of VC investment than might at first be imagined. Further work is, however, necessary in order to test this hypothesis. Following the approach adopted in section 5, an initial test would involve classifying corporate insolvency laws according to their degree of 'debtor friendliness' and then examining how these findings relate to levels of early-stage private equity investment.

The analysis in this paper has a number of implications for ongoing policy debates. Generally, a number of recent national and EU initiatives have sought explicitly to encourage innovative firms and venture capital finance. For example, the European Commission's Risk Capital Action Plan is designed to stimulate this type of activity throughout Member States (European Commission, 1998; 2000). The UK Government has set itself the goal of making Britain the 'best place in the world to start and grow a business' (Small Business Service (UK), 2001: 3). The stimulation of the market for venture capital will clearly play an important part in this process, and an understanding of the determinants of venture capital investment is of obvious importance in achieving this objective. As explained in section 3, factors which operate to affect the demand for venture capital - such as, it has been argued, personal insolvency law - are likely to be more significant in a world where investment capital can relocate across borders more readily than entrepreneurs.

The claims developed in this paper have particular implications for developments in the field of insolvency law. Under the aegis of the Risk Capital Action Plan, the European Commission identified the need to facilitate the 'softening of bankruptcy laws to allow failed entrepreneurs a second chance...' (European Commission, 2000). This initiative has now lead to a final report with a range of general recommendations for reducing the stigma associated with business failure (European Commission Expert Group, 2003). ${ }^{33} \mathrm{~A}$ specific example of the implementation of policy thinking of this type is the UK's Enterprise Act 2002, which contains a number of features designed to reduce the harshness of personal insolvency for individuals who have become bankrupt simply because of bad luck (Department of Trade and Industry (UK), 2001). Under the new legislation, the time to automatic discharge will from April 2004 be reduced to 12 months. ${ }^{34}$ Furthermore, the legal disabilities associated with the status of undischarged bankrupt will be scrapped, as a bid to send a signal to society that bankruptcy should carry less stigma. These policy reports and initiatives all assume that changes to insolvency laws may have an impact on attitudes to entrepreneurship, although little in the way of statistical analysis has been conducted. This paper provides preliminary support for the validity of the assumption.

\footnotetext{
${ }^{33}$ These were based upon a wide-ranging review of EU member states' insolvency laws commissioned by the EC: Philippe \& Partners (2002).

${ }^{34}$ However, if fraud is shown then the bankrupt may be made subject to a Bankruptcy Restraining Order which will, inter alia, prohibit him from being involved in the management of a company for a period of 515 years.
} 
However, to say that changes in bankruptcy law may increase or decrease demand for venture capital finance does not necessarily imply that such a result will be desirable. Relaxing bankruptcy laws will stimulate poor business proposals as well as good ones. Furthermore, if personal bankruptcy is relaxed to stimulate entrepreneurship. Establishing the 'optimal' level of entrepreneurial risk-taking is a policy question well beyond the scope of this paper. Indeed, proposed reforms in the US which would restrict access to personal bankruptcy is motivated by a desire to restrict the 'excessive' availability of bankruptcy discharge. The Bankruptcy Abuse and Consumer Protection Act 2002, ${ }^{35}$ which narrowly failed in Congress in 2003, would have seen the introduction of meanstesting for debtors who wish to make use of Chapter 7 proceedings, requiring those whose incomes are above a certain threshold instead to make use of the Chapter 13 procedure, which involves a composition with creditors as opposed to an outright discharge (American Bankruptcy Institute, 2002). This paper predicts that these reforms might, if they had been passed, have had the effect of making entrepreneurship less attractive at the margins. Whether this is desirable or not, is, of course, a different matter.

\section{References}

Aghion, Phillipe, and Patrick Bolton. 1992. 'An Incomplete Contracts Approach to Financial Contracting’, 59 Review of Economic Studies 473-494.

American Bankruptcy Institute. 2002. 'Major Effects of the Consumer Bankruptcy Provisions of the 2002 Bankruptcy Legislation', available at: $<$ http://www.abiworld.org/table.pdf $>$.

Armour, John. 2003. 'Law, Finance and Innovation: A Review', in J.A. McCahery and L. Renneboog (eds.) Venture Capital Contracting and the Valuation of Hi-Tech Firms (Oxford: Oxford University Press), 133-161.

Armour, John and Cumming, Douglas C. 2004. 'The Legal Road to Replicating Silicon Valley' CBR Working Paper No. ___ (March 2004), available at: $<$ www.cbr.cam.ac.uk/publications/index.htm>.

Baird, Douglas G., and Picker, Randal C. 1991. 'A Simple Noncooperative Bargaining Model of Corporate Reorganizations’, 20 Journal of Legal Studies 311.

Baygan, Günseli and Michael Freudenberg. 2000. 'The Internationalisation of Venture Capital Activity in OECD Countries: Implications for Measurement and Policy', OECD STI Working Paper 2000/7.

Bebchuk, Lucian Ayre, and Chang, Howard. 1992. 'Bargaining and the Division of Value in Corporate Reorganization', 8 Journal of Law, Economics, and Organization 253-279.

${ }^{35}$ HR 33 (Conference Report: H Rep 107-617). The Bill failed in Congress in 2003. 
Bell, J., Boyron, S. and Whittaker, S. 1998. Principles of French Law (Oxford: OUP).

Berger, Allen N. and Gregory F. Udell. 1998. 'The Economics of Small Business Finance: The Roles of Private Equity and Debt Markets in the Financial Growth Cycles', 22 Journal of Banking \& Finance 613-673.

Black, Bernard S. 2001. 'Does Corporate Governance Matter? A Crude Test Using Russian Data' 149 University of Pennsylvania Law Review 2131-2150.

Black, Bernard S., and Ronald J. Gilson. 1998. 'Venture Capital and the Structure of Capital Markets: Banks Versus Stock Markets’ 47 Journal of Financial Economics 243-277.

Bratton, William W. 2002. 'Venture Capital on the Downside: Preferred Stock and Corporate Control', 100 Michigan Law Review 891-945.

Cappiello, S. 2002. 'Bankruptcy Procedures in Italy' 13 International Company and Commercial Law Review 260-265.

Carpenter, R.E. and B.C. Petersen. 2002. 'Capital Market Imperfections, High-Tech Investment, and New Equity Financing’ 112 Economic Journal F54-F72.

Cherubini, G. 2000. ‘Bankruptcy Reform in Italy’, Eurofenix October 2000, 13.

Corcoran, Elizabeth. 2002. 'Digital Diaspora; From the Internet wreckage, the Spirit of Silicon Valley Emerges’, 169(4) Forbes.

Cremades, B.M. 1992. Business Law in Spain, $2^{\text {nd }}$ edn. (London, Butterworths).

Cumming, Douglas J. and Jeffrey G. MacIntosh. 2002. 'Crowding Out Private Equity: Canadian Evidence' working paper, University of Toronto Law School/ University of Alberta Business School, available at: <www.ssrn.com>.

Czarnetzky, John M. 2000. 'The Individual and Failure: A Theory of the Bankruptcy Discharge’ 32 Arizona State Law Journal 393-464.

Dalloz. 1955-. Dalloz Encyclopédie Juridique: Répertoire de Procédure Civile et Commerciale (Paris: Dalloz).

Department of Trade and Industry (UK). 2001. Productivity and Enterprise: Insolvency A Second Chance (London, TSO).

Dirix, E. 2001. 'Bankruptcy Arrangements: The Belgian Case', in Vriesendorp, R.D., McCahery, J.A. and Verstijlen, F.M.J. (eds.), Comparative and International Perspectives on Bankruptcy Law Reform in the Netherlands (The Hague: Boom Juridische Uitgevers), 171-182. 
European Commission. 1998. Risk Capital: A Key to Job Creation in the European Union, Brussels 31 March 1998, SEC (1998)552 final.

European Commission. 2000. Progress Report on the Risk Capital Action Plan, Brussels 18 Oct 2000, COM (2000) 658 final.

European Commission (DG Enterprise) Expert Group. 2003. Best Project on Restructuring, Bankruptcy and a Fresh Start: Final Report (Brussels).

EVCA (European Private Equity and Venture Capital Association). 1998-. EVCA Yearbooks (Bruges: EVCA).

Fan, Wei and Michelle J. White. 2000. 'Personal Bankruptcy and the Level of Entrepreneurial Activity’, working paper, University of Michigan.

Fletcher, Ian F. 2003. The Law of Insolvency, $3^{\text {rd }}$ edn. (London: Sweet \& Maxwell).

Freedman, Judith, and Michael Godwin. 1994. 'Incorporating the Micro Business: Perceptions and Misperceptions', in Alan Hughes and Donald J. Storey, Finance and the Small Firm (London: Routledge. 232.

Gangopadhyay, Shubhashis, and Wihlborg, Clas. 2001. 'The Impact of Bankruptcy Rules on Risky Project Choice and Skill Formation under Credit Rationing', working paper available on SSRN.

Gebhard, Robert S. 2000. 'Dot-com Bankruptcies: A Preview from Silicon Valley?’, 19 American Bankruptcy Institute Journal 6.

Georgellis, Y., and Wall, H.J. 2002. 'Entrepreneurship and the policy environment’ Federal Reserve Bank of St. Louis Working Paper 2002-019A. $<$ http://reseach.stlouisfed.org/wp/2002/2002-019.pdf >.

Georgokopoulos, Nicholas L. 2002. 'Bankruptcy Law for Productivity’ 37 Wake Forest Law Review 51-95.

Gilson, Ronald J., and David M. Schizer. 2003. 'Understanding Venture Capital Structure: A Tax Explanation for Convertible Preferred Stock’ 116 Harvard law Review 874-916.

Gompers, Paul A. and Josh Lerner. 1999. The Venture Capital Cycle (Cambridge, MA: MIT Press).

Gompers, Paul A. and Josh Lerner. 2000. 'What Drives Venture Capital Fundraising?' NBER Working Paper 6906.

Gompers, Paul A. and Josh Lerner. 2001. 'The Venture Capital Revolution', 15(2) Journal of Economic Perspectives 145-168. 
Gonzalez, Ignacio Guillen. undated. 'Spanish Insolvency Law', available at: $<$ www.multilaw.com $>$.

Hagg, M. 1997. 'Sweden: Insolvency Procedures' 8 International Company and Commercial Law Review C20-C21.

Hallinan, Charles G. 1986. 'The 'Fresh Start' Policy in Consumer Bankruptcy: A Historical Inventory and an Interpretative Theory' 21 University of Richmond Law Review 49-160.

Hart, Oliver. 1995. Firms, Contracts and Financial Structure (Oxford: Clarendon Press).

Hicks, Andrew, Robert Drury and Janet Smallcombe. 1995. Alternative Company Structures for the Small Business, ACCA Research Report (London: Certified Accountants Educational Trust).

INSOL Europe (eds.). undated. Technical Releases: Insolvency Systems in Europe $<$ http://www.insol-europe.org/member_forum.htm>.

Jackson, Thomas H. 1985. 'The Fresh-Start Policy in Bankruptcy Law’ 98 Harvard law Review 1393-1448.

Jeng, Leslie A. and Wells, Philippe C. 2000. 'The Determinants of Venture Capital Funding: Evidence Across Countries’ 6 Journal of Corporate Finance 241-289.

Jensen, Michael C., and William H. Meckling. 1976. 'Theory of the Firm: Managerial Behaviour, Agency Costs and Ownership Structure’, 3 Journal of Financial Economics 305-360.

Klausner, Michael and Kate Litvak. 2001. 'What Economists Have Taught US About Venture Capital Contracting', in Michael J. Whincop (ed.), Bridging the Entrepreneurial Finance Gap: Linking Governance with Regulatory Policy (Aldershot: Ashgate), 54-74.

Koral, R.L. and Sordino, M.-C. 1996. 'The New Bankruptcy Reorganization Law in France: Ten Years Later’ 70 American bankruptcy Law Journal 437-458.

Kortum, S., and J. Lerner. 2000. 'Assessing the contribution of venture capital to innovation' 31 RAND Journal of Economics 647-692.

La Porta, Rafael, Lopes-de-Silanes, Florencio, Shleifer, Andrei and Vishny, Robert W.,. 1997. 'Law and Finance', 52 Journal of Finance 1131-1150.

Mayer, Colin. 2001. 'Institutional Investment and Private Equity in the UK', Oxford University Saïd Business School Working Paper 2001-FE-10. 
Myers, Stewart C., and Nicholas S. Majluf. 1984. 'Corporate Financing and Investment Decisions When Firms Have Information That Investors Do Not Have', 13 Journal of Financial Economics 187-221.

Paulus, C.G. 2001. 'Germany: Lessons to Learn from the Implementation of a New Insolvency Code’, 17 Connecticut Journal of International Law 89-98.

Philippe \& Partners. 2002. Bankruptcy and a Fresh Start: Stigma on Failure and Legal Consequences of Bankruptcy, Study Prepared for European Commission (Brussels).

Raaijmakers, Theo. 2001. 'Towards a Further Revision of Dutch Insolvency Law', in R.D. Vriesendorp, J.A. McCahery and F.M.J. Verstijlen (eds.), Comparative and International Perspectives on Bankruptcy Law Reform in the Netherlands (The Hague: Boom Juridische uitgevers), 3-12.

Sanfey, Mark and Holohan, Bill. 1991), Bankruptcy Law and Practice in Ireland (Dublin: Round Hall Press).

Schiller, C. 2002. 'Three Years of Insolvency Plans in Germany', Eurofenix March 2002, 4-5.

SJ Berwin (eds.). 2002. Bankruptcy and Insolvency: EVCA Tax \& Legal Committee Special Paper (Zaventum: EVCA).

Small Business Service (SBS). 2001. Think Small First (London: SBS).

Sorenson, A. and Omar, P.J. 1996. Corporate Rescue Procedures in France (London, Kluwer Law International).

Tabb, Charles Jordan. 1997. The Law of Bankruptcy (Westbury, NY: Foundation Press).

Tykvová, T. 2000. Venture capital in Germany and its impact on innovation. Working paper, Centre for European Economic Research (ZEW), University of Mannheim (available from SSRN).

Triantis, G.G. 2001. 'Financial Contract Design in the World of Venture Capital', 68 University of Chicago Law Review 305-323.

Vermeulen, Erik. 2001. 'Towards a New 'Company' Structure for High-Tech Start-Ups in Europe', working paper, Tilburg University Centre for Company Law (available from SSRN).

Wessels, Bob. 1999. Business and Bankruptcy Law in the Netherlands (The Hague: KluwerLaw International).

Wood, Phillip. 1995. Principles of International Insolvency (London: Sweet \& Maxwell). 
Wood, P. and Totty, P.G. (eds.). 1994. Butterworths International Insolvency Laws (London: Butterworths).

Ziechmann, P. 1997. 'Business Bankruptcy in Germany’ American Bankruptcy Institute Journal 16 February 1997, 10.

\section{APPENDIX: PERSONAL INSOLVENCY LAWS OF DifFERENT COUNTRIES}

Most jurisdictions support at least two procedures - a 'pure bankruptcy' proceeding in which the debtor's assets are liquidated, and a 'composition' or 'arrangement' mechanism whereby debts may be rescheduled by agreement with creditors. The discussion focuses on the former, as this will represent the background against which any composition negotiations will take place.

Many jurisdictions restrict access to certain types of insolvency proceeding to 'commercial' parties, which typically encompasses both corporations and individuals who are involved in running a business. Where such a restriction exists, it is assumed that entrepreneurs of the sort discussed in section 4 would be classified as 'commercial' parties, and detailed consideration is not given to procedures which are applicable only to consumers.

[Insert Table 5 about here]. 
Figure 1: Venture Capital Investment (early stage and expansion), by Country

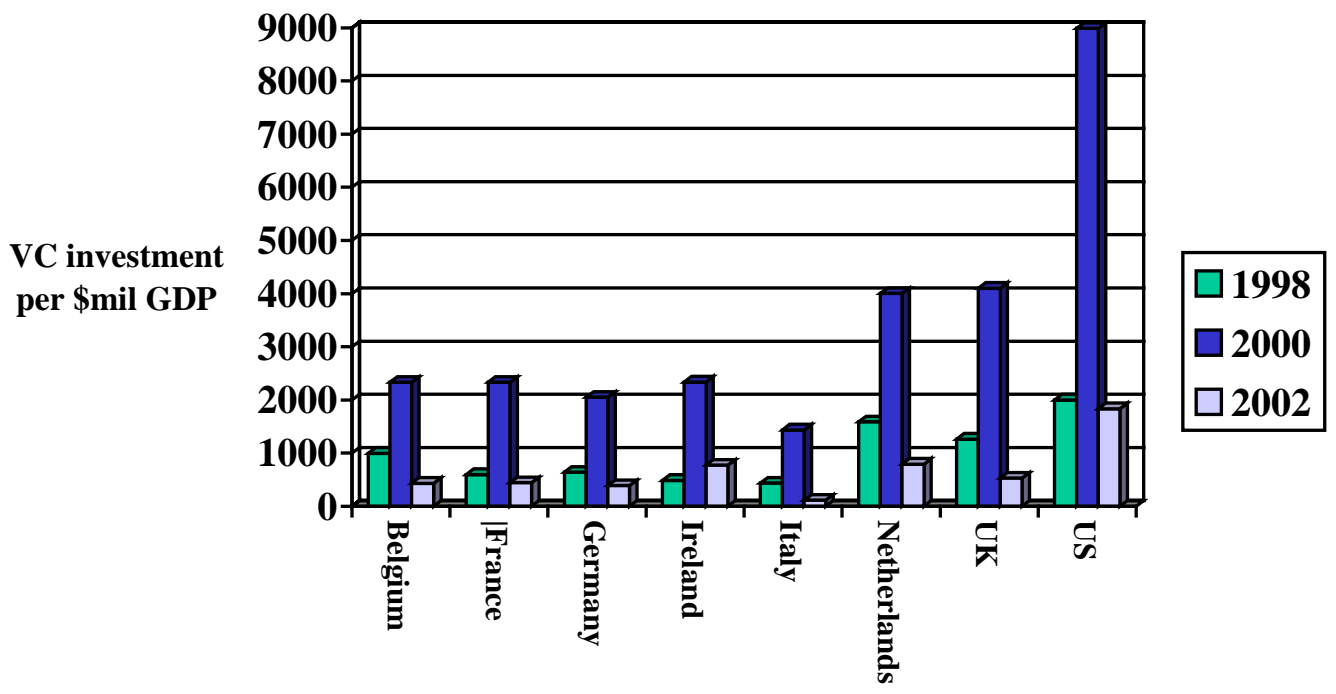

(Sources: EVCA, PwC MoneyTree/Venture Economics/NVCA, OECD). 
Table 1: Index of 'Severity’ of Personal Insolvency Laws

\begin{tabular}{|c|c|c|c|c|c|c|c|c|c|c|c|}
\hline & 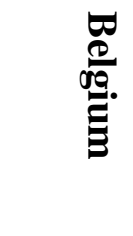 &  & 预 & 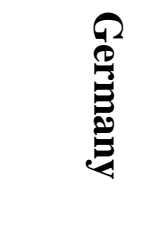 & 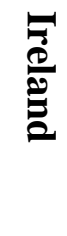 & $\overrightarrow{\underline{\vec{\theta}}}$ & 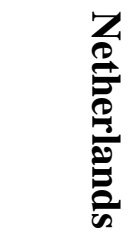 & 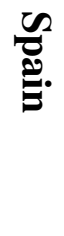 & 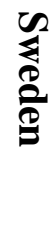 & $\stackrel{ }{\lambda}$ & E \\
\hline $\begin{array}{l}\text { Years to } \\
\text { Discharge }\end{array}$ & $0(-)$ & - & 0 & $7(-)$ & 12 & - & $3(-)$ & - & - & 3 & 0 \\
\hline $\begin{array}{l}\text { Date of } \\
\text { change }\end{array}$ & 08.08 .97 & - & - & 01.01 .99 & - & - & 01.12 .98 & - & - & - & - \\
\hline $\begin{array}{l}\text { 'Severity' } \\
\text { index }\end{array}$ & $1(5)$ & 5 & 3 & 1(5) & 4 & 5 & $2(5)$ & 5 & 5 & 2 & 1 \\
\hline
\end{tabular}


Table 2: VC (early stage and expansion) Investment per \$m of GDP(a)

\begin{tabular}{rrrrr}
\hline \hline Country & \multicolumn{1}{c}{1997} & \multicolumn{1}{c}{1998} & \multicolumn{1}{c}{1999} & \multicolumn{1}{c}{$\mathbf{2 0 0 0}$} \\
\hline Belgium & 734.30 & 999.49 & 2419.68 & 2331.99 \\
Denmark & 143.37 & 246.32 & 505.54 & 1032.21 \\
France & 405.04 & 597.60 & 1117.02 & 2334.64 \\
Germany & 425.75 & 638.56 & 1246.91 & 2051.91 \\
Ireland & 481.93 & 485.97 & 901.63 & 2337.82 \\
Italy & 217.56 & 436.09 & 479.76 & 1438.43 \\
Netherlands & 1407.96 & 1586.46 & 2644.03 & 4001.87 \\
Spain & 378.05 & 354.22 & 846.21 & 1415.45 \\
Sweden & 233.43 & 515.70 & 1657.88 & 2265.81 \\
UK & 1003.31 & 1262.92 & 1831.66 & 4100.28 \\
US & 1537.93 & 2001.35 & 5069.15 & 8986.24 \\
& & & & \\
\hline
\end{tabular}

a Sources: EVCA, PwC MoneyTree/Venture Economics/NVCA, OECD (2002 prices and exchange rates) 
Table 3: Descriptive Statistics

\begin{tabular}{|l|r|r|r|r|r|}
\hline & $\mathrm{N}$ & \multicolumn{1}{|c|}{ Minimum } & \multicolumn{1}{|c|}{ Maximum } & \multicolumn{1}{|c|}{ Mean } & Std. Deviation \\
\hline $\begin{array}{l}\text { "Severity" of Personal } \\
\text { Insolvency Laws }\end{array}$ & 44 & 1.00 & 5.00 & 3.7481 & 1.3960 \\
$\begin{array}{l}\text { VC Investment per \$m } \\
\text { GDP }\end{array}$ & 44 & 143.37 & 8986.24 & 1525.2140 & 1592.2669 \\
$\begin{array}{l}\text { Ln (VC Investment per } \\
\text { \$mil GDP) }\end{array}$ & 44 & 4.97 & 9.10 & 6.9284 & .9143 \\
Valid N (listwise) & 44 & & & & \\
\hline
\end{tabular}


Figure 2: Raw Data: VC Investment and Severity of Personal Insolvency Laws

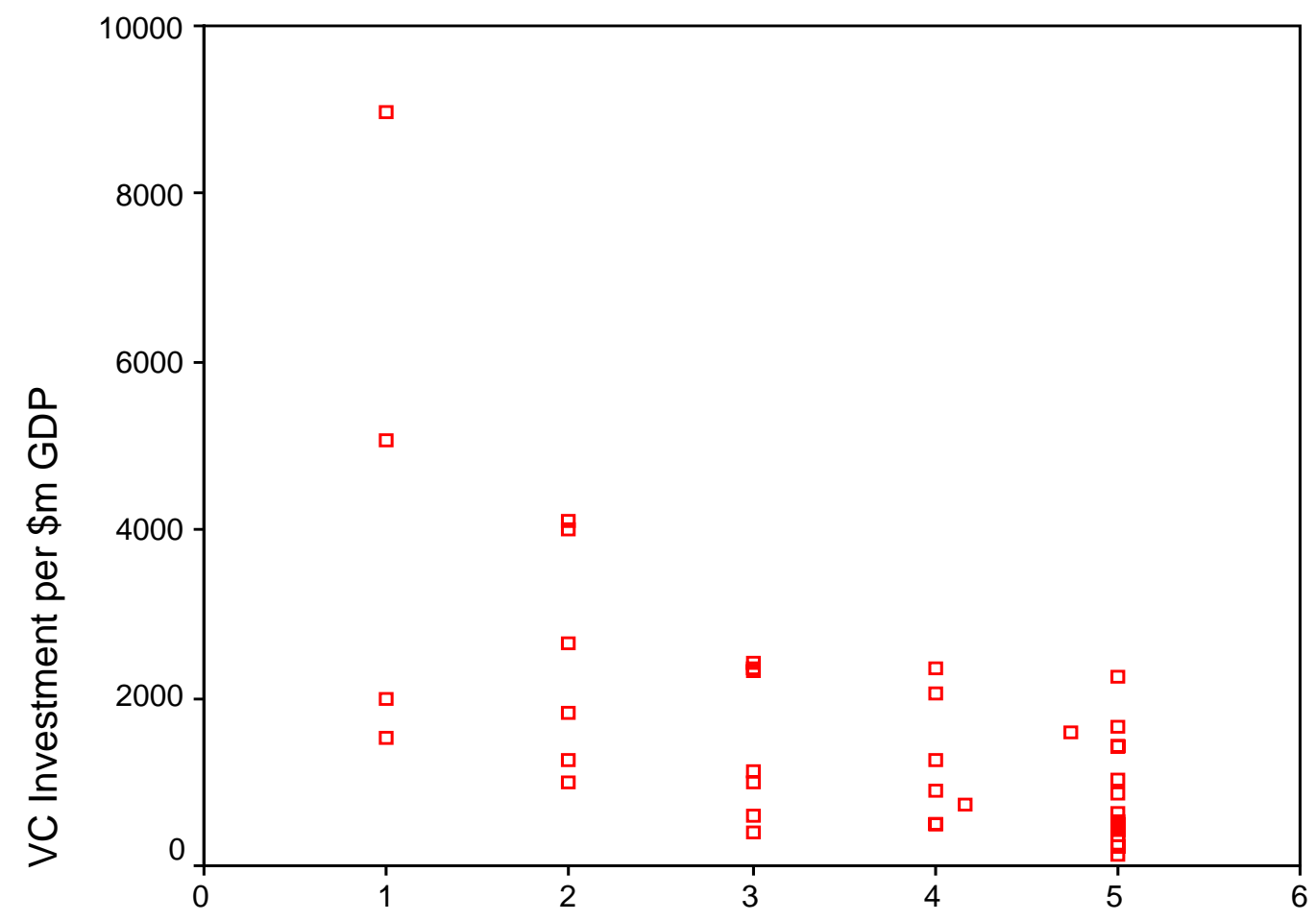

"Severity" of Personal Insolvency Laws 
Table 4: Nonparametric Tests for Correlation of VC Investment with 'Severity' of Personal Insolvency Laws

\begin{tabular}{|c|c|c|c|c|}
\hline & & & $\begin{array}{l}\text { "Severity" of } \\
\text { Personal } \\
\text { Insolvency } \\
\text { Laws }\end{array}$ & $\begin{array}{c}\text { VC } \\
\text { Investment } \\
\text { per \$m GDP }\end{array}$ \\
\hline \multirow[t]{5}{*}{ Kendall's tau_b } & $\begin{array}{l}\text { "Severity" of Personal } \\
\text { Insolvency Laws }\end{array}$ & $\begin{array}{l}\text { Correlation } \\
\text { Coefficient } \\
\text { Sig. (2-tailed) }\end{array}$ & 1.000 & $\begin{array}{r}-.493(* *) \\
.000\end{array}$ \\
\hline & & $\mathrm{N}$ & 44 & 44 \\
\hline & $\begin{array}{l}\text { VC Investment per } \\
\$ \mathrm{~m} \text { GDP }\end{array}$ & $\begin{array}{l}\text { Correlation } \\
\text { Coefficient }\end{array}$ & $-.493\left({ }^{* \star}\right)$ & 1.000 \\
\hline & & Sig. (2-tailed) & .000 & \\
\hline & & $\mathrm{N}$ & 44 & 44 \\
\hline \multirow[t]{4}{*}{ Spearman's rho } & $\begin{array}{l}\text { "Severity" of Personal } \\
\text { Insolvency Laws }\end{array}$ & $\begin{array}{l}\text { Correlation } \\
\text { Coefficient } \\
\text { Sig. (2-tailed) }\end{array}$ & 1.000 & $\begin{array}{r}-.621\left({ }^{* *}\right) \\
.000\end{array}$ \\
\hline & & $\mathrm{N}$ & 44 & 44 \\
\hline & $\begin{array}{l}\text { VC Investment per } \\
\text { \$m GDP }\end{array}$ & $\begin{array}{l}\text { Correlation } \\
\text { Coefficient } \\
\text { Sig. (2-tailed) }\end{array}$ & $\begin{array}{r}-.621(* *) \\
.000\end{array}$ & 1.000 \\
\hline & & $\mathrm{N}$ & 44 & 44 \\
\hline
\end{tabular}

** Correlation is significant at the .01 level (2-tailed). 
Figure 3: Ln(VC Investment per \$m GDP) and Severity of Personal Insolvency Law

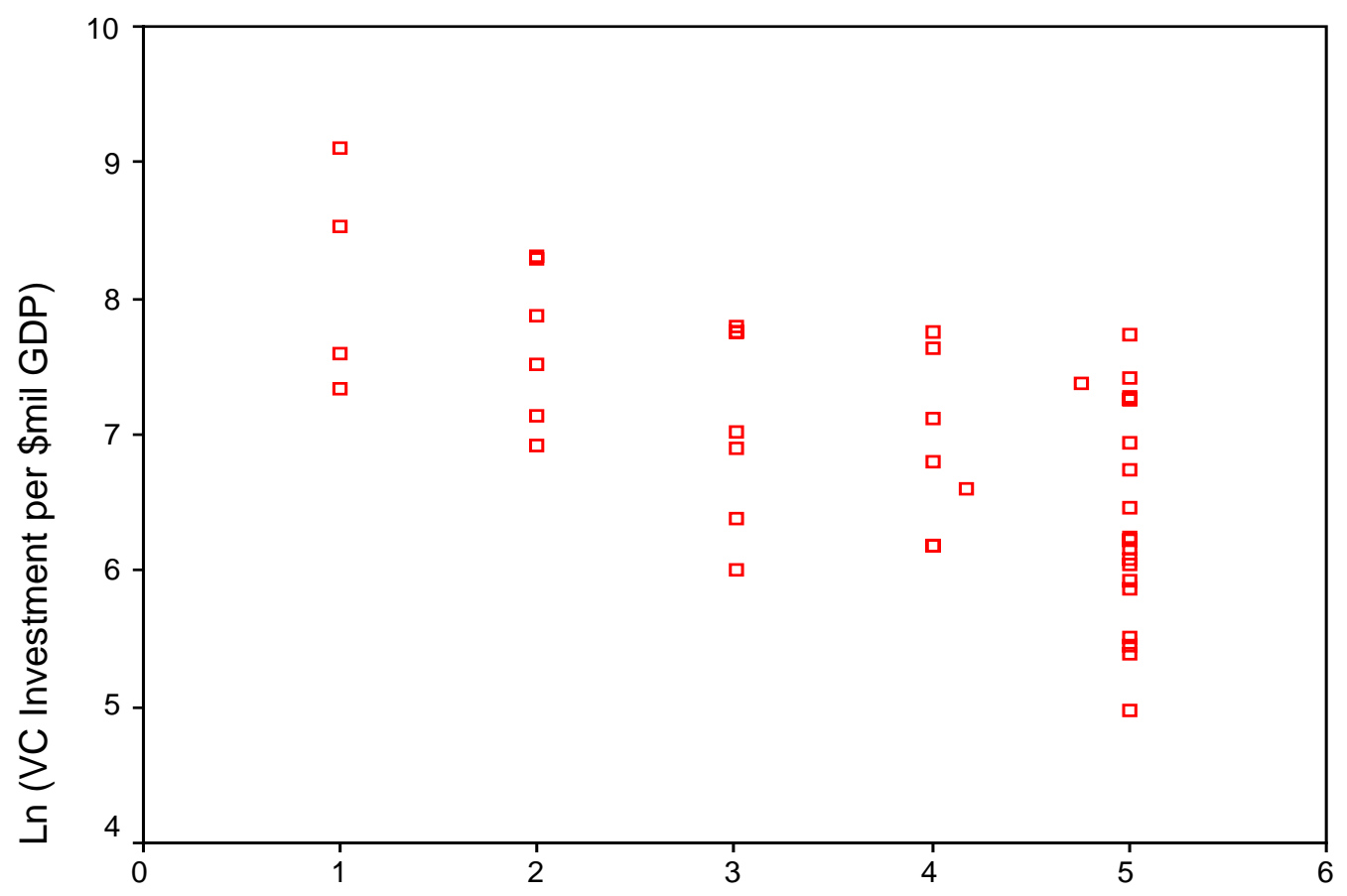

"Severity" of Personal Insolvency Laws 
Table 5: Availability of Discharge under Personal Insolvency Law

\begin{tabular}{|c|c|c|c|c|c|c|}
\hline Country & Relevant Legislation & \multicolumn{4}{|c|}{ Discharge for Individual Insolvents } & References \\
\hline BELGIUM & \multicolumn{2}{|c|}{$\begin{array}{l}\text { Concordat Act (Law of } 17 \text { July 1997) and Bankruptcy Act (Law } \\
\text { of } 8 \text { August 1997); Collective Debt Rescheduling for Private } \\
\text { Persons Act (Law of } 5 \text { July 1998) in Arts 1675/2-17 of the } \\
\text { Judicial Code. }\end{array}$} & \multicolumn{3}{|c|}{$\begin{array}{l}\text { Prior to } 1997 \text { reforms, no discharge available. Discharge now available to } \\
\text { commercial parties at discretion of court following completion of bankruptcy } \\
\text { proceedings. No specific guidelines on exercise of discretion under the Bankruptcy } \\
\text { Act; generally accepted that discharge granted where debtor 'excusable'. }\end{array}$} & $\begin{array}{l}\text { Philippe et al, 2002: 274; } \\
\text { Dirix, 2001: 172. }\end{array}$ \\
\hline DENMARK & \multicolumn{2}{|c|}{$\begin{array}{l}\text { Bankruptcy Act of } 9 \text { September 1986, Bankruptcy Act No } 402 \text { of } \\
26 \text { June } 1998 .\end{array}$} & \multicolumn{3}{|c|}{$\begin{array}{l}\text { No discharge is available, and the debtor remains liable for unpaid debts after the } \\
\text { proceedings close. }\end{array}$} & $\begin{array}{l}\text { INSOL Europe, undated; } \\
\text { SJ Berwin, 2002: 43-45. }\end{array}$ \\
\hline FRANCE & \multicolumn{3}{|c|}{$\begin{array}{l}\text { Prevention of Business Difficulties Law (Law No. 84-148 of } 1 \text { March 1984), } \\
\text { Insolvency Law (Law No. 85-98 of } 25 \text { January 1985), Insolvency } \\
\text { Practitioners Law (Law No. 85-99 of } 25 \text { January 1985) and Insolvency } \\
\text { Reform Law (Law No. 94-475 of } 10 \text { June 1994). }\end{array}$} & $\begin{array}{l}\text { Discharge is available at the end of the liquidation } \\
\text { proceedings on the discretion of the court, provided the } \\
\text { debtor has not been fraudulent }\end{array}$ & \multicolumn{2}{|c|}{$\begin{array}{l}\text { Dalloz, 1955-; Bell et al, 1998; Sorenson } \\
\text { and Omar, 1996; Koral and Sordino, } \\
\text { 1996; INSOL Europe, undated. }\end{array}$} \\
\hline GERMANY & Insolvenzordnung of 1 January 1999. & \multicolumn{4}{|c|}{$\begin{array}{l}\text { Prior to 1999, no discharge available. Since } 1 \text { January 1999, discharge available if debtor promises } \\
\text { to sign over majority of income to creditors for } 7 \text { years following completion of proceedings- } \\
\text { effectively discharge period of } 7 \text { years. Lowered to } 6 \text { years in } 2001 \text {. }\end{array}$} & $\begin{array}{l}\text { Ziechmann, 1997; Paulus, } \\
\text { 2001; Schiller, 2002. }\end{array}$ \\
\hline IRELAND & \multicolumn{2}{|l|}{ Bankruptcy Act 1988.} & \multicolumn{3}{|c|}{$\begin{array}{l}\text { Discharge available at court's discretion, usually granted on proof of payment of } \\
50 \% \text { of creditors' claims, or } 12 \text { years following commencement of proceedings. }\end{array}$} & $\begin{array}{l}\text { Sanfey and Holohan, } \\
\text { 1991; SJ Berwin, } 2002 .\end{array}$ \\
\hline ITALY & \multicolumn{2}{|c|}{$\begin{array}{l}\text { R.D. } 16 \text { March 1942, n. 267. (The Bill of } 27 \text { October } 2000 \\
\text { delegates to Italian government the power to reform Italian } \\
\text { bankruptcy law) }\end{array}$} & \multicolumn{2}{|c|}{$\begin{array}{l}\text { No discharge available for individual debtors unless the creditors } \\
\text { consent to a composition. }\end{array}$} & \multicolumn{2}{|c|}{$\begin{array}{l}\text { Wood and Totty, 1994: 259-312; } \\
\text { Cherubini, 2000; Cappiello, 2002; SJ } \\
\text { Berwin, 2002: 17-21. }\end{array}$} \\
\hline $\begin{array}{l}\text { NETHER- } \\
\text { LANDS }\end{array}$ & $\begin{array}{l}\text { Bankruptcy Act } 1893 \text { (Faillissementswet); } \\
\text { Natural Persons Debt Rescheduling (Natural } \\
\text { Persons) Act } 1998 \text { (Wet Schuldsanering } \\
\text { Natuurlijke Personen) (in force } 1 \text { December } \\
\text { 1998). }\end{array}$ & \multicolumn{4}{|c|}{$\begin{array}{l}\text { No discharge available in liquidation proceedings. However, under a debt rescheduling agreement, } \\
\text { available since } 1 \text { December 1998, individual willing to pay over all personal earnings (except for } \\
\text { minimum set by court) and maintain good conduct obtains discharge after } 3 \text { years. Must } \\
\text { demonstrate willingness to negotiate with creditors, but need not actually achieve a voluntary } \\
\text { compromise-court will impose restructuring plan if no agreement reached. }\end{array}$} & $\begin{array}{l}\text { Wessels, 1999: 95-108; } \\
\text { Raaijmakers, 2001; SJ } \\
\text { Berwin, 2002: 33-35. }\end{array}$ \\
\hline SPAIN & \multicolumn{2}{|c|}{$\begin{array}{l}\text { Civil Procedure Act of the Commercial Codes of } 1829 \text { and } \\
\text { 1885; Payments Act of } 1922\end{array}$} & \multicolumn{2}{|c|}{$\begin{array}{l}\text { No discharge/requalification available without consent of creditors } \\
\text { to a composition. }\end{array}$} & \multicolumn{2}{|c|}{$\begin{array}{l}\text { Cremades, 1992: 183-198; Wood and } \\
\text { Totty, 1994: 649-733; SJ Berwin, 2002: } \\
\text { 22-27; Gonzalez, undated }\end{array}$} \\
\hline SWEDEN & \multicolumn{3}{|c|}{$\begin{array}{l}\text { Rights of Priority Act (1970: 979); Floating Charges Act (1984: 649); } \\
\text { Bankruptcy Act (1987: 672); Reorganisation Act (1996: 764). }\end{array}$} & \multicolumn{2}{|l|}{ Discharge is not available for individual debtors. } & $\begin{array}{l}\text { Hagg, 1997; SJ Berwin, } \\
\text { 2002: 40-42. }\end{array}$ \\
\hline UK & Insolvency Act 1986; Enterprise Act 2002. & \multicolumn{4}{|c|}{$\begin{array}{l}\text { Discharge is available three years after commencement of bankruptcy proceedings, provided debtor } \\
\text { not fraudulent. If previously discharged than } 9 \text { years beforehand, then discharge only available at } \\
\text { the discretion of the court. If the total debts less than } £ 20,000 \text {, discharge after two years. From } \\
\text { April } 2004 \text {, the Enterprise Act } 2002 \text { will introduce an expedited discharge ( } 1 \text { year) for bankrupts } \\
\text { not found by court to have taken irresponsible risks. }\end{array}$} & Fletcher, 2003. \\
\hline USA & Bankruptcy Reform Act 1978 & \multicolumn{4}{|c|}{$\begin{array}{l}\text { Discharge immediately available when Chapter } 7 \text { proceedings end, provided debtor has not been } \\
\text { discharged in preceding } 6 \text { years. Law due to be modified to make it more difficult for individual } \\
\text { insolvents to enter Chapter } 7 \text { proceedings. }\end{array}$} & Tabb, 1997. \\
\hline
\end{tabular}

